Article Type: Research Paper

\title{
Total Financing of Islamic Rural Banks and Regional Macroeconomic Factors: A Dynamic Panel Approach
}

\section{Faaza Fakhrunnas}

\section{OPEN}

\section{AFFILIATION:}

Department of Economics, Faculty Business and Economics, Universitas Islam Indonesia. Yogyakarta. Indonesia.

\section{*CORRESPONDENCE:}

Fakhrunnasfaaza@uii.ac.id

THIS ARTICLE IS AVALILABLE IN:

http://journal.umy.ac.id/index.php/esp

DOI: $10.18196 /$ jesp.21.1.5028

\section{CITATION:}

Fakhrunnas, F. (2020). Total Financing of Islamic Rural Banks and Regional Macroeconomic Factors: A Dynamic Panel Approach. Jurnal Ekonomi \& Studi Pembangunan, 21(1), 1-15.

\section{ARTICLE HISTORY}

\section{Received:}

12 January 2020

Reviewed:

19 April 2020

Revised:

20 April 2020

Accepted:

21 April 2020
Abstract: Islamic rural bank is a special purpose of Islamic banks, which finances Small and Medium Enterprises (SMEs) in Indonesia. This research aims to investigate a long-run relationship of the influence of regional inflation and economic growth on the total financing of Islamic rural banks in Indonesia. By adopting panel dynamics approach, this study utilized a biggest Islamic rural bank in each Indonesian province from 2013 to 2017 based on quarterly data, which consisted of 420 observation period. The result of this study exhibited that a longrun relationship existed among regional inflation and economic growth to the total financing of Islamic rural banks. Specifically, the long-run relationship also appeared in big size Islamic rural banks, although it was not in small and medium size Islamic rural banks. Variance decompositions and Impulse response factors analysis' result explained that the majority of all regional macroeconomic variables contributed to the influence of total financing on the Islamic rural bank. The directions of its influence were different from each sample group. According to the results, Indonesian central bank must maintain inflation rate in the safety level for financial industry by following determined inflation target through appropriate monetary policies. This recommendation for the central bank is aimed to maintain and boost Islamic rural banks' financing that will give benefits for financial industry in Indonesia.

Keywords: Total Financing, Regional Inflation, Regional Economic Growth. JEL Classification: E00. E42, G00.

\section{Introduction}

In terms of economic conditions, Indonesia, as one of the most populous countries in the world, has an economic atmosphere mainly propped by Small Medium Enterprises (SMEs). Asia Pacific Foundation of Canada (2018) in its report notes that SMEs in Indonesia contribute about $60 \%$ of the total Gross Domestic Product (GDP). However, one of the foremost problems of SMEs, including in Indonesia, is access to capital (Chiu, 2017). Thus, the role of the Islamic bank industry led by Islamic rural banks is pivotal to serve SMEs' needs as a capital provider, especially at the microfinancing level. As an intermediary institution for SMEs, the bank has a role in linking from a surplus unit to a deficit unit by utilizing several modes of contract. The financing activity is not only about the capital, but also fulfilling the requirement of Islam to avoid riba as the value of the 
Indonesian majority population who embrace Islam as a belief (Juwana, Berlinti, \& Dewi, 2014).

Regarding the development of Islamic banks in Indonesia, the establishment of the bank was firstly driven by Islamic society with forming Islamic microfinance in 1990. Sari, Bahari, and Hamat (2016) added that since the willingness of the Islamic society in Indonesia was supported by many Islamic scholars who issued the fatwa of Indonesian Ulama Council (Majelis Ulama Indonesia) to prohibit usury (riba), the first Islamic bank was finally established in 1992, named Bank Muamalat Indonesia (BMI). For the current development, at the beginning of 2018, Indonesian Financial Service Authority stated that Islamic banking industry consisted of 13 Islamic commercial banks, 21 conventional banks having Islamic business unit, and 167 Islamic rural banks, with total asset more than IDR 424 trillion, and it was equal to almost $6 \%$ of market share in the Indonesian banking industry (OJK, 2018).

According to the data issued by the Indonesian Financial Service Authority in 2018, Islamic rural banks in Indonesia provided several modes of financing, such as mudarabah, musharakah, murabahah, ijarah, istishna, salam, qard, and hybrid contract (OJK, 2018). The data is exhibited in Figure 1. in which generally, all transactions in each contract had a positive trend. In addition, murabahah contract, as a cost-plus financing contract, remained dominant compared to others. The total financing from murabahah contract approximately reached IDR 6 trillion in the year of 2017. This number contributed around $80 \%$ on average from 2013 to 2017 . Meanwhile, equity-based financing, proposed by mudharabah and musharakah, had less financing numbers as opposed to murabahah. The average number of equity-based financing each year was not more than IDR 1 trillion. In another method of contract, the only a hybrid contract, which had more than $5 \%$ of total financing performed by Islamic rural banks in Indonesia, was equal to almost IDR 500 billion on average for every year.

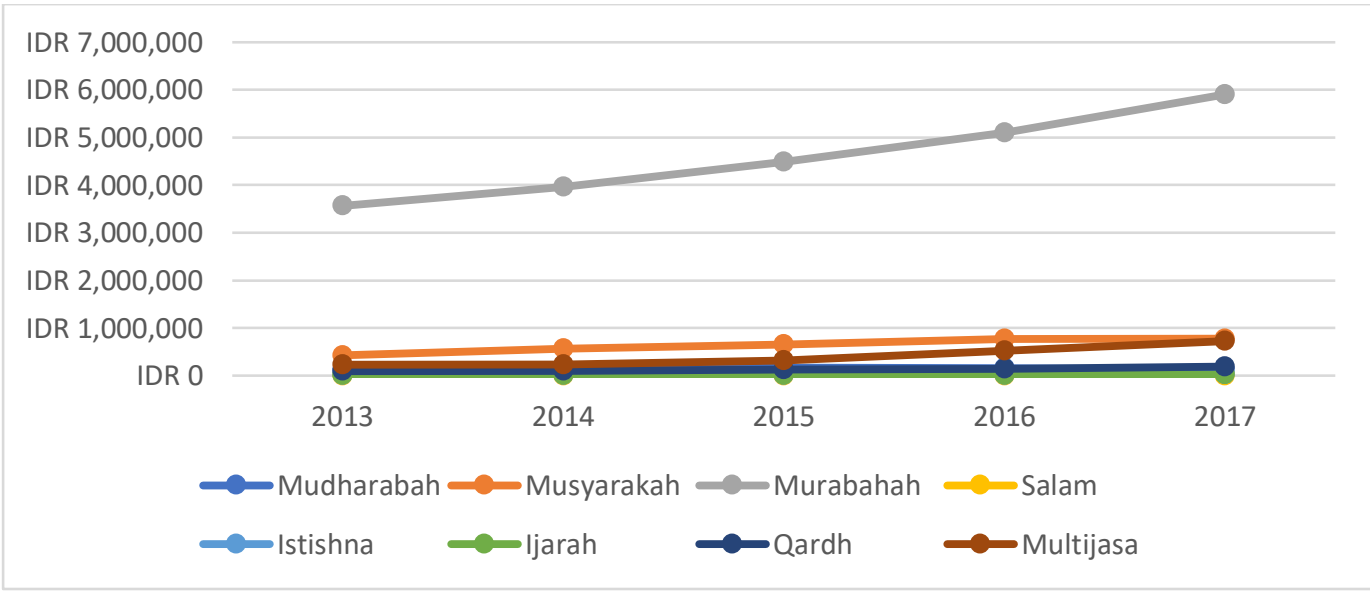

Figure 1 Islamic Rural Bank Financing in Indonesia Period 2013 to 2017 (In IDR Million) Source: OJK (2018) 
The evidence from the figure also portrays that the majority of financing activity conducted by Indonesian Islamic rural banking adopted debt-based financing, which has been similar to the conventional banks because it has been alleged to have a strong relationship to interest rate (Chong \& Liu, 2009). Furthermore, Abedifar, Molyneux, and Tarazi (2013) stated that every method of financing would have unique exposure to macroeconomic risk, which would influence the Islamic bank's financial performance. The transmission of macroeconomic variables, such as inflation, economic growth, and its influence on the bank's financing activity, can be seen in many research. Benczúr, Karagiannis, and Kvedaras (2018) confirmed that economic growth influenced financing activity in the bank. Economic growth is one of the signals to assess the economic conditions in certain regions. In a good economic growth, business activities tend to have a good response from society to have higher demands for goods and services. Then, financing activity will support these business activities to keep growing. Zarrouk, Ben Jedidia, and Moualhi (2016) believed that an Islamic bank would be affected by macroeconomic conditions in which the bank preferred to have good economic growth. The bank tends to have better performance, while economic conditions incline to rise. Zarrouk et al. (2016) stressed that an Islamic bank would engage in more financing activity during good economic circumstances. Fakhrunnas, Dari, and Mifrahi (2018) also declared that the Gross Domestic Product (GDP) affected banking performance in Indonesia. However, there were differences in the result when the sample was differentiated between Islamic banks and conventional banks. Adopting Fully Modified Ordinary Least Square (FMOLS) and Dynamic Ordinary Least Square (DOLS) model, the conventional bank has pro-cyclical response performance to GDP. On the other hand, the performance of Islamic banks has not been influenced significantly by GDP. From this finding, it can be concluded that Islamic bank had more resilience to GDP movement risk than its counterparty (Fakhrunnas et al., 2018).

Another factor that affects the Islamic bank's financial performance is inflation (Fakhrunnas \& Imron, 2019). Inflation is considered as one of the key factors which can determine economic condition. Imam and Kpodar (2016) claim that inflation may lower economic growth because of its effect on increasing prices and decreasing society's purchasing power. Inflation had a direct effect on the bank's financing in the financial market. This argument was conveyed by Carlos, Ferreira, and Mendonça (2011), who found that the central bank might increase the interest rate to limit the money supply in the market due to an increase in inflation. However, inflation controlling, which may increase interest rate through central bank monetary policy, can become a burden on Islamic banks while giving financing to deficit units. As a result, a rise in inflation will lessen Islamic bank financing in the market. The reason for this occurrence is stated by Chong and Liu (2009) who believe that Islamic bank still depends on the interest rate as a benchmark to determine the return. The use of interest rate as a benchmark is mainly adopted in debt-based contracts, such as murabahah.

The unfavorable effect of inflation on the bank's financing was also found by Boyd and Champ (2006). They added that inflation would negatively affect bank profitability in the condition that the bank had less awareness while the inflation started to move upward. Different from other results, Tan and Floros (2012) uncovered that inflation had a 
significant relationship with the bank's performance. The bank is considered to have a favorable adjustment to a change of interest rate during undesirable economic circumstances that create a faster increase in revenue than the cost spent by the bank. The same finding is also obtained by other studies, such as Garcia-Herrero, Gavilá, and Santabárbara (2009), and Sufian (2009). In terms of the bank size, Ibrahim, and Rizvi (2017) claims that Islam bank that has a big size is more stable compared to other sizes. This statement is supported by several reasons; such is the big bank has better risk management and a bigger economic scale, which can create more efficient and effective banking operations.

The majority of the previous research about the bank's financing determinants mainly utilized Islamic commercial banks as the research object. The domination of Islamic commercial banks as research objects might be caused by the availability of the data across countries. However, the use of Islamic rural banks as an object study that serves the society at a microfinancing level is still rare when it is referred to as indexed international publication. The research object is believed to be essential to reveal its uniqueness as a sort of Islamic banking operating at microfinance level. As a research contribution, this study aims to measure the Indonesian Islamic rural bank financing in a short and long-run analysis by engaging regional macroeconomic factors in each province as independent variables. Specifically, this study tries to answer two main research questions; (1) what is the influence of a short and long-run economic growth and (2) what is the influence of short and long-run inflation.

This paper consists of the introduction as the first section, and it is followed by the research method. In the third section, results and discussion will be explained while the fourth section shows the conclusion.

\section{Research Method}

The description of the variables used is shown in Table 1. It consisted of LN_TP as a dependent variable that reflected total financing in Islamic rural banks. REG and RINF were the independent variables, which would test their influence on the total financing of Islamic rural banks. Moreover, LN_SIZE would be treated as a control variable in this research. By adopting purposive samples, this research only selected the biggest size of Islamic rural banks that operated in each province, which had complete financial reports in the observation period. The biggest Islamic rural bank in each province was believed to have an economic scale and efficiency to be measured its performance towards the influence of regional economic factors. Based on data selection, this study obtained 21 Islamic rural banks in 21 provinces, which resulted in 420 banks in the observation period. All the data were in a balanced panel form, where it was started from 2013 to 2017 in the quarterly period. Then, it was retrieved from the Indonesian Financial Service Authority and Indonesian Statistic Bureau. 
Fakhrunnas

Total Financing of Islamic Rural Banks and Regional Macroeconomic Factors: ...

Table 1 Descriptive Information of Variables Used

\begin{tabular}{|c|c|c|c|}
\hline Variable & Notation & Description & Data Source \\
\hline Total Financing & LN_TP & $\begin{array}{l}\text { Log total financing of Islamic } \\
\text { rural bank }\end{array}$ & $\begin{array}{l}\text { Indonesian Financial } \\
\text { Service Authority }\end{array}$ \\
\hline $\begin{array}{l}\text { Regional } \\
\text { Economic } \\
\text { Growth }\end{array}$ & REG & $\begin{array}{l}\text { Regional economic growth in } \\
\text { each province in percentage }\end{array}$ & $\begin{array}{l}\text { Indonesian Statistic } \\
\text { Bureau }\end{array}$ \\
\hline $\begin{array}{l}\text { Regional } \\
\text { Inflation }\end{array}$ & RINF & $\begin{array}{l}\text { Regional economic growth in } \\
\text { each province in percentage }\end{array}$ & $\begin{array}{l}\text { Indonesian } \\
\text { Bureau }\end{array}$ \\
\hline Bank Size & LN_SIZE & $\begin{array}{l}\text { Log Islamic rural bank's total } \\
\text { asset }\end{array}$ & $\begin{array}{l}\text { Indonesian Financial } \\
\text { Service Authority }\end{array}$ \\
\hline
\end{tabular}

Model Specification

In this paper, panel data was adopted. It means that cross-section and time-series data were pooled to measure the influence of regional macroeconomic factors, in which the proxies were regional inflation and regional economic growth on the total financing of Islamic rural banks. From that objective, the equation is as follow;

$$
\log T F=f\left(R I N F, R E G, L N \_S I Z E\right)
$$

From the above equation, the empirical model form can be elaborated, as below,

$$
L N_{-} T P_{i t}=\beta_{0}+\beta_{1} R I N F_{i t}+\beta_{2} R E G_{i t}+\beta_{3} L N_{-} S I Z E_{i t}+\varepsilon_{i t}
$$

$\beta 0$ expresses the constant term of the equation, in which $\beta 1$ to $\beta 3$ are estimated parameters in the model. In addition, I describes cross-section data, reflecting the biggest Islamic rural bank in each province level, $t$ explains about time-series data, and $\varepsilon$ it appoints an error term in this model.

\section{Estimation Procedure}

Panel dynamics were applied to analyze the relationship among variables in this research. To perform panel dynamics, cointegration among variables should be attained, which was firstly checked by unit-roots tests. Pedroni (2000) argues that panel dynamics provide an option for the researchers to pool the long-run information inside the panel data, and it allows long dynamic and fixed effect exists in the estimation model. Panel dynamics also give a chance to the researcher to have extensive data (Perron, 1991). Moreover, Pedroni $(2000,2004)$ states that cross-section data are permitted for a presence that reflects interdependence with a different individual effect. There were several stages to conduct panel dynamics, which would be explained in the next discussion.

\section{Panel Cointegration Test}

To perform the panel cointegration test, the unit-roots test should be conducted previously. The Unit-roots test would measure the stationarity of the data, whether it 
stood at the level of the first difference and second difference. Some mathematical measurements can be adopted to conduct unit-root tests, such as Im, Pesaran, and Shin W-stat (IPS), ADF-fisher, and PP-Fisher, in which the null hypothesis of the test is nonstationary for all unit-roots test (Zulkhibri, Naiya, \& Ghazal, 2015). When the test results show the stationarity data in the first difference, then the cointegration panel can be applied to assess the long-term effect of the future relationship among observed variables.

Levin, Lin, and Chu (2002) suggest the model of panel unit-roots estimate long-run relationship, as follows:

$$
y_{i t}=\rho_{i} y_{i, t-1}+z^{\prime}{ }_{i t} \gamma+\mu_{i t}
$$

Where $z_{i t}$ is defined as deterministic variables, $\mu_{i t}$ is as iid $\left(0, \sigma^{2}\right)$, and $\rho_{i}=\rho$. The statistic test is exactly at t-statistic on $\rho$ in which it is explained as below;

$$
t_{\rho}=\frac{(-1) b \pm \sqrt{b^{2}-4 a c}}{2 a}
$$

The general formula for Pedroni tests is as follow;

Panel rho-statistic:

$$
Z_{\rho}=\left(\sum_{i=1}^{N} \sum_{t=1}^{T} \hat{L}_{11 i}^{-2} \hat{e}_{i t-1}^{2}\right)^{-1} \sum_{i=1}^{N} \sum_{t=1}^{T} \hat{L}_{11 i\left(\hat{e}_{i t-1} \Delta \hat{e}_{i t}-\widehat{\lambda}_{i}\right)}
$$

Panel PP-statistic:

$$
Z_{P P}=\left(\hat{\sigma}^{2} \sum_{i=1}^{N} \sum_{t=1}^{T} \hat{L}_{11 i}^{-2} \hat{e}_{i t-1}^{2}\right)^{-1 / 2} \sum_{i=1}^{N} \sum_{t=1}^{T} \hat{L}_{11 i\left(\hat{e}_{i t-1} \Delta \hat{e}_{i t}-\widehat{\lambda}_{i}\right)}
$$

Panel ADF-statistic:

$$
Z_{t}=\left(\hat{S}^{* 2} \sum_{\mathrm{i}=1}^{N} \sum_{t=1}^{T} \hat{L}_{11 i}^{-2} \hat{e}_{i t-1}^{* 2}\right)^{-1 / 2} \sum_{\mathrm{i}=1}^{N} \sum_{t=1}^{T} \hat{L}_{11 i\left(\hat{e}_{i t-1}^{*} \Delta \hat{e}_{i t}^{*}\right)}
$$

Group rho-statistic:

$$
\hat{Z}_{\rho}=\sum_{i=1}^{N}\left(\sum_{t=1}^{T} \hat{e}_{i t-1}^{2}\right)^{-1} \sum_{i=1}^{T}\left(\hat{e}_{i t-1} \Delta \hat{e}_{i t}-\hat{\lambda}_{i}\right)
$$


Group PP-statistic:

Group ADF-statistic:

$$
\hat{Z}_{t}=\sum_{i=1}^{N}\left(\hat{\sigma}^{2} \sum_{t=1}^{T} \hat{e}_{i t-1}^{2}\right)^{-1 / 2} \sum_{\mathrm{i}=1}^{T}\left(\hat{e}_{i t-1} \Delta \hat{e}_{i t}-\hat{\lambda}_{i}\right)
$$

$$
\hat{Z}_{P P}=\sum_{i=1}^{N}\left(\sum_{t=1}^{T} \hat{S}_{i}^{-2} \hat{e}_{i t-1}^{* 2}\right)^{-1 / 2} \sum_{i=1}^{T}\left(\hat{e}_{i t-1}^{*} \Delta \hat{e}_{i t}^{*}\right)
$$

Variance Decompositions and Impulse Response Factors

The use of Variance Decompositions (VDs) and Impulse Response Factors (IRFs) aimed to measure the multivariate causalities among variables. Moreover, it can capture the sample more in the observation period in terms of relative strength and its causality (Rosylin \& Bahlous, 2013). VDs would portray the causality relationship among the observed variables. VDs also provided a variety of changes in terms of the value of a variable over the observed period. In addition, to estimate IFRs, Panel VAR analysis should be conducted to understand the long-term effect of the determinants of Islamic banks' financing. Pesaran and Shin (1999) believed that IFRS would assess the time profile of the effect shock from the determined point of time to the future value of the observed variable in a dynamic system. Not only giving the future prediction, but IFRs would also provide future direction of the observed variable.

\section{Result and Discussion}

Unit roots and Panel Cointegration Result

The unit-roots test was used to check the stationary of the variables. This test would assess whether the variables were stationary at a level or at 1st difference as a requirement to apply further tests (Pedroni, 2004). Table 2 describes the unit-roots test for Islamic rural banks in the observed period. From the table, it can be seen that only RINF had stationarity at the level by adopting an individual intercept. However, the results were different when individual intercept and trend were applied to measure stationarity. RINF, REG, and LN_SIZE had stationarity at the level, but not for LN_TP. Besides, both applying individual intercept only and individual intercept and trend were stationary at the 1st level. This result is the same as the perspective of Im Pesaran Shin, AugmentedDickey Fuller (ADF), and Philip Perron (PP). From the result mentioned above, all samples in this research were stationary at the 1 st level, and it fulfilled the requirement to conduct a cointegration test that measured the long-run relationship among the variables.

In the cointegration test, several approaches were carried out. Within the dimension approach, panel v-statistic, panel rho-statistic, panel PP-statistic, and Panel ADF-statistic were applied. In addition, between dimensions, group rho-statistic, group PP-statistic, and Group ADF-statistic were utilized to assess the research model. As suggested by Rosylin 
and Bahlous (2013); and Fakhrunnas et al. (2018), the result of the cointegration test can be seen from the majority result of all approaches. At least forth out of seven tests were significant at level $1 \%, 5 \%$, and $10 \%$. Table 3 . exhibits the result of the panel cointegration test, which portrayed the different results among observed samples that were differentiated based on the Islamic rural bank's size.

From all samples, Islamic rural bank financing (LN_TP) had a long-run relationship toward the endogenous variables, such as regional inflation and economic growth. This finding is supported by (Farhan, Sattar, Chaudhry, and Khalil, 2012), which stated that economic growth would impact the bank's performance. Furthermore, Garcia-Herrero et al., (2009); and Sufian (2009) also mentioned that inflation would affect the bank's performance. A long-run relationship among the variables also indicated that the bank should be aware of the movement of regional economic growth and regional inflation at the province level because it had a long-run effect on the total financing in Islamic rural banks.

When the sample was separated based on the size of the Islamic rural bank, the result of the cointegration test was different. From the small size Islamic rural bank, the cointegration did not exist since only Panel ADF-stat and Group ADF-stat were significant in the $10 \%$ and $5 \%$ level, respectively. The finding implies that there was no long-run relationship of small size Islamic rural bank's financing to regional inflation and economic growth. The reason might be caused by the small size of Islamic rural bank, which did not have a large-scale financing activity, did not influence the regional inflation, and economic growth in the long-term period. This finding is also different from Ibrahim and Rizvi (2017), who stated that a small size Islamic bank was riskier than the big size one. The finding of small size Islamic rural banks is almost the same as the medium size of Islamic rural banks. Only Panel PP-stat, Group PP-stat, and Group ADF-stat that had a significant result in the $1 \%-10 \%$ level of significance. From an inward-looking Islamic rural bank, both sizes of the bank might also be resilient to regional inflation and economic growth because there was no long-run relationship toward observed variables in this research (Fakhrunnas et al., 2018).

For the big-sized Islamic rural bank, the result was different from other sizes, which exhibited long-run relationships among total financing, regional inflation, and economic growth appear. The finding explained that there was an influence of regional inflation and economic growth on the total financing of the bank. It is supported by Boyd and Champ (2006), Tan and Floros (2012), and Farhan et al. (2012), who also concluded that the bank performance would be affected by macroeconomic variables, such as inflation and economic growth. The high exposure to the external factors does not mean that Islamic rural bank is weak to manage the risk. The advantage of having a big size of Islamic rural bank is to possess a wide economic scale compared to other Islamic rural bank's sizes. The big size bank internally tends to have good risk management, and it creates stability in the banking operation (Ibrahim \& Rizvi, 2017). 
Fakhrunnas

Total Financing of Islamic Rural Banks and Regional Macroeconomic Factors: ...

Table 2 Panel Unit Root Tests of Islamic Rural Bank in Indonesia Period 2013Q1-2017Q4

\begin{tabular}{|c|c|c|c|c|c|c|c|c|c|c|c|c|}
\hline \multirow{3}{*}{ Variable } & \multicolumn{6}{|c|}{ Individual Intercept } & \multicolumn{6}{|c|}{ Individual Intercept and Trend } \\
\hline & \multicolumn{3}{|c|}{ At Level } & \multicolumn{3}{|c|}{ first Difference } & \multicolumn{3}{|c|}{ At Level } & \multicolumn{3}{|c|}{ first Difference } \\
\hline & IPS & ADF & PP & IPS & ADF & PP & IPS & ADF & PP & IPS & ADF & PP \\
\hline LN_TP & 0.495 & 40.20 & 64.12 & $-8.847 * * *$ & $157.5^{* * *}$ & $483.6 * * *$ & 0.807 & 32.72 & 40.58 & $-8.368 * * *$ & $142.6 * * *$ & $212.0 * * *$ \\
\hline RINF & $-4.616 * * *$ & $91.38 * * *$ & $143.7 * * *$ & $-12.35 * * *$ & $217.6 * * *$ & $1480 * * *$ & $-3.466 * * *$ & $83.62 * * *$ & $141.2 * * *$ & $-9.465 * * *$ & $160.7 * * *$ & $376.9 * * *$ \\
\hline REG & -1.191 & 49.09 & 96.04 & $-11.91 * * *$ & $208.7 * * *$ & $941.6 * * *$ & $-3.498 * * *$ & $74.99 * * *$ & $114.4^{* * *}$ & $-8.764 * * *$ & $148.9 * * *$ & $356.1 * * *$ \\
\hline LN_SIZE & 1.610 & 35.36 & 38.09 & $-11.51 * * *$ & $203.9 * * *$ & $710.7^{* * *}$ & $-2.416 * * *$ & $73.87 * * *$ & $60.32 * * *$ & $-9.642 * * *$ & $165.0 * * *$ & $267.9 * * *$ \\
\hline
\end{tabular}

Notes: The optimal lag length is based on Schwarz information criteria, which are automatically selected. The Null hypothesis for all tests is non-stationary in which $* * *, * *$ and ${ }^{*}$ denote as significant at $1 \%$ level, significant at $5 \%$ level and significant at $10 \%$ level

Table 3 Panel Cointegration Tests of Islamic Rural Bank in Indonesia Period 2013Q1-2017Q4

\begin{tabular}{|c|c|c|c|c|}
\hline Cointegration Test & All Sample & Small Size & Medium Size & Big Size \\
\hline \multicolumn{5}{|c|}{ Within Dimension } \\
\hline Panel v-stat & -0.858 & 0.265 & -0.238 & $2.030 * *$ \\
\hline Panel rho-stat & -0.503 & 0.863 & 0.841 & -0.501 \\
\hline Panel PP-stat & $-2.571 * * *$ & -0.253 & $-1.543^{*}$ & $-4.354 * * *$ \\
\hline Panel ADF-stat & $-3.036 * * *$ & $-1.522 *$ & -1.213 & $-4.675^{* * *}$ \\
\hline \multicolumn{5}{|c|}{ Between Dimension } \\
\hline Group rho-stat & 1.74 & 1.818 & 2.296 & 0.830 \\
\hline Group PP-stat & $-2.748 * * *$ & -0.045 & $-3.241 * * *$ & $-6.519 * * *$ \\
\hline Group ADF-stat & $-4.422 * * *$ & $-2.280 * *$ & $-1.801 * *$ & $-5.865 * * *$ \\
\hline
\end{tabular}

Notes: The symbol of $* * *, * *$ and* denotes as significant at $1 \%$ level, significant at $5 \%$ level and significant at $10 \%$ level 
Fakhrunnas

Total Financing of Islamic Rural Banks and Regional Macroeconomic Factors: ...

Variance Decompositions Result

\section{Table 4 Variance Decompositions Result}

\begin{tabular}{|c|c|c|c|c|c|c|c|c|c|c|c|c|c|c|c|c|c|c|c|c|}
\hline \multirow[t]{2}{*}{ Period } & \multicolumn{5}{|c|}{$\begin{array}{l}\text { Variance Decomposition of LN_TP (All } \\
\text { Sample) }\end{array}$} & \multicolumn{5}{|c|}{$\begin{array}{c}\text { Variance Decomposition of LN_TP (Small Size } \\
\text { Bank) }\end{array}$} & \multicolumn{5}{|c|}{$\begin{array}{l}\text { Variance Decomposition of LN_TP (Medium } \\
\text { Size Bank) }\end{array}$} & \multicolumn{5}{|c|}{$\begin{array}{l}\text { Variance Decomposition of LN_TP (Big Size } \\
\text { Bank) }\end{array}$} \\
\hline & S.E. & LN_TP & RINF & REG & LN_SIZE & S.E. & LN_TP & RINF & REG & LN_SIZE & S.E. & LN_TP & RINF & REG & LN_SIZE & S.E. & LN_TP & RINF & REG & LN_SIZE \\
\hline $2013 Q 1$ & 0.11 & 100.00 & 0.00 & 0.00 & 0.00 & 0.21 & 100.00 & 0.00 & 0.00 & 0.00 & 0.06 & 100 & 0 & 0 & 0 & 0.06 & 100.00 & 0.00 & 0.00 & 0.00 \\
\hline $2013 Q 2$ & 0.17 & 97.16 & 0.00 & 0.30 & 2.54 & 0.31 & 98.59 & 0.13 & 0.57 & 0.71 & 0.11 & 98.524 & 0.04 & 0.81 & 0.62 & 0.10 & 92.11 & 0.17 & 0.02 & 7.70 \\
\hline $2013 Q 3$ & 0.21 & 93.01 & 0.09 & 0.20 & 6.70 & 0.38 & 93.72 & 0.29 & 0.52 & 5.47 & 0.14 & 97.522 & 0.16 & 0.66 & 1.66 & 0.13 & 87.03 & 0.37 & 0.12 & 12.48 \\
\hline $2013 Q 4$ & 0.25 & 87.91 & 0.24 & 0.17 & 11.68 & 0.42 & 89.31 & 0.62 & 0.43 & 9.65 & 0.17 & 96.542 & 0.11 & 1.05 & 2.30 & 0.16 & 87.99 & 0.60 & 0.20 & 11.21 \\
\hline 2014Q1 & 0.27 & 82.37 & 0.37 & 0.26 & 16.99 & 0.46 & 85.35 & 1.00 & 0.37 & 13.28 & 0.19 & 95.168 & 0.08 & 1.82 & 2.93 & 0.19 & 88.24 & 0.69 & 0.21 & 10.86 \\
\hline 2014Q2 & 0.30 & 76.85 & 0.47 & 0.43 & 22.26 & 0.49 & 81.99 & 1.58 & 0.33 & 16.10 & 0.22 & 93.53 & 0.07 & 2.71 & 3.69 & 0.21 & 87.46 & 0.87 & 0.22 & 11.46 \\
\hline $2014 Q 3$ & 0.32 & 71.58 & 0.51 & 0.66 & 27.25 & 0.51 & 79.14 & 2.20 & 0.30 & 18.36 & 0.24 & 91.69 & 0.08 & 3.79 & 4.43 & 0.23 & 87.31 & 1.02 & 0.22 & 11.44 \\
\hline $2014 Q 4$ & 0.34 & 66.70 & 0.51 & 0.93 & 31.86 & 0.53 & 76.61 & 2.79 & 0.28 & 20.31 & 0.26 & 89.713 & 0.11 & 5.01 & 5.16 & 0.25 & 87.40 & 1.14 & 0.23 & 11.23 \\
\hline 2015Q1 & 0.36 & 62.26 & 0.48 & 1.22 & 36.03 & 0.55 & 74.38 & 3.41 & 0.27 & 21.94 & 0.27 & 87.629 & 0.16 & 6.33 & 5.88 & 0.26 & 87.26 & 1.22 & 0.23 & 11.29 \\
\hline 2015Q2 & 0.38 & 58.27 & 0.44 & 1.52 & 39.77 & 0.57 & 72.40 & 4.01 & 0.26 & 23.33 & 0.29 & 85.496 & 0.23 & 7.69 & 6.59 & 0.28 & 87.14 & 1.29 & 0.23 & 11.34 \\
\hline 2015Q3 & 0.40 & 54.69 & 0.41 & 1.81 & 43.09 & 0.58 & 70.62 & 4.56 & 0.26 & 24.56 & 0.3 & 83.356 & 0.30 & 9.08 & 7.27 & 0.29 & 87.14 & 1.33 & 0.23 & 11.29 \\
\hline 2015Q4 & 0.42 & 51.49 & 0.37 & 2.10 & 46.04 & 0.59 & 69.00 & 5.09 & 0.26 & 25.65 & 0.32 & 81.235 & 0.38 & 10.46 & 7.92 & 0.31 & 87.12 & 1.35 & 0.24 & 11.29 \\
\hline 2016Q1 & 0.43 & 48.62 & 0.35 & 2.38 & 48.65 & 0.61 & 67.53 & 5.59 & 0.25 & 26.62 & 0.33 & 79.161 & 0.47 & 11.83 & 8.53 & 0.32 & 87.08 & 1.37 & 0.24 & 11.32 \\
\hline 2016Q2 & 0.45 & 46.06 & 0.33 & 2.64 & 50.97 & 0.62 & 66.19 & 6.05 & 0.25 & 27.51 & 0.35 & 77.149 & 0.57 & 13.17 & 9.12 & 0.33 & 87.06 & 1.38 & 0.24 & 11.32 \\
\hline 2016Q3 & 0.47 & 43.76 & 0.33 & 2.89 & 53.03 & 0.63 & 64.95 & 6.48 & 0.25 & 28.32 & 0.36 & 75.211 & 0.66 & 14.46 & 9.67 & 0.35 & 87.05 & 1.39 & 0.24 & 11.32 \\
\hline $2016 Q 4$ & 0.48 & 41.69 & 0.33 & 3.12 & 54.86 & 0.65 & 63.81 & 6.88 & 0.25 & 29.06 & 0.37 & 73.356 & 0.76 & 15.71 & 10.18 & 0.36 & 87.03 & 1.40 & 0.24 & 11.33 \\
\hline 2017Q1 & 0.50 & 39.82 & 0.34 & 3.35 & 56.49 & 0.66 & 62.75 & 7.25 & 0.25 & 29.75 & 0.39 & 71.588 & 0.85 & 16.90 & 10.67 & 0.37 & 87.02 & 1.40 & 0.24 & 11.34 \\
\hline 2017Q2 & 0.51 & 38.13 & 0.36 & 3.55 & 57.96 & 0.67 & 61.77 & 7.59 & 0.25 & 30.39 & 0.4 & 69.907 & 0.94 & 18.03 & 11.12 & 0.38 & 87.01 & 1.41 & 0.24 & 11.34 \\
\hline $2017 Q 3$ & 0.53 & 36.59 & 0.38 & 3.74 & 59.28 & 0.68 & 60.85 & 7.92 & 0.25 & 30.98 & 0.41 & 68.315 & 1.03 & 19.11 & 11.55 & 0.39 & 86.99 & 1.42 & 0.25 & 11.34 \\
\hline 2017Q4 & 0.54 & 35.20 & 0.41 & 3.92 & 60.46 & 0.70 & 60.00 & 8.22 & 0.25 & 31.53 & 0.43 & 66.809 & 1.12 & 20.13 & 11.94 & 0.40 & 86.98 & 1.43 & 0.25 & 11.34 \\
\hline
\end{tabular}

Jurnal Ekonomi \& Studi Pembangunan, 2020 | 10 
Rosylin and Bahlous (2013) explained that VDs would portray the influence of the independent variables on the dependent variable. Table 4. shows the VDs test result, which was divided by the characteristic of the sample according to the Islamic rural bank's size. In all samples, it can be seen that regional inflation affected $0.51 \%$ in the period of 2014Q4 as the maximum point, even though after that period, it tended to decrease until the end of the observation period. On the other hand, regional economic growth was consistent to increase and had the maximum influence on Islamic rural bank's financing at $3.92 \%$. The Islamic rural bank's size affected $60.46 \%$ of the bank's financing in $2017 \mathrm{Q}$. For the small size Islamic rural bank, the influence of regional inflation on Islamic rural bank financing was consistent to increase time by time. The maximum influence was in 2017 Q 4 that affected by $8.22 \%$ on the bank's financing. However, the result was different from regional economic growth, in which the influence had a downward trend, which had the highest point in 2012Q2, amounting to $0.57 \%$, and it reached the lowest influence in 2017Q4, which was $0.25 \%$. This finding implies that in the small size Islamic rural bank, regional inflation in the short run had a greater influence than regional economic growth. Moreover, the direction of the influence contradicted each sample group mentioned above.

For the medium size Islamic rural bank, the influence of regional inflation had an upward trend, which had a peak point at $1.12 \%$, which reflected that the effect of regional inflation on total financing of Islamic rural banks was at that percentage. The same trend was also possessed by regional economic growth, which had the optimum influence on Islamic rural bank's total financing at $20.13 \%$. The influence of size to Islamic rural bank's total financing was lower than the small size Islamic rural bank, which was $11.94 \%$ and $31.53 \%$, respectively. Besides, the big size Islamic rural bank in the short run had the same trend as medium size Islamic rural bank. However, there was a difference in terms of the number. In the regional inflation variable, the minimum to maximum influence on total financing of Islamic rural banks was from $0.17 \%$ to $1.43 \%$. Furthermore, regional economic growth only had a small influence on the total financing of Islamic rural banks, which was from $0.02 \%$ to $0.25 \%$. According to the result discussed previously, in the short run, the influence of independent variables on the dependent variable varied. It connotes that every Islamic rural bank, which was grouped based on size, had a specific result in each group.

Impulse Response Factors

Impulse Response Factors (IRFs) were employed to understand each direction of the independent variable to the dependent variable in each group of the sample. Pesaran and Shin (1999) stated that IRFs would give information about the direction of one variable to other variables in each step of the observation period. The period used in IFRS was 20 observation period, which started from the 1st quarter of 2013 to the 4th quarter of 2017 with applying Non-factorized One S.D IRFs. From all samples, regional inflation tended to have an upward movement to influence the total financing of Islamic rural banks. In the beginning, the movement of regional inflation toward total financing almost increased in the 2 nd quarter of 2013, and it dropped in the 3rd quarter of 2017, then it increased consistently, and it tended to be stable in the 1st quarter of 2016. In addition, regional economic growth tended to have fluctuated direction in terms of the influence on total 
financing of Islamic rural banks. Starting to rise in the 1st quarter of 2013, the regional economic growth had a negative direction and was below the horizontal zero lines during the observation period. On the other hand, the size of Islamic rural banks has increased dramatically since around the 2 nd period of observation, which was in the 2nd quarter of 2013. Then, the direct effect of financing tended to be stable.

Figure 2 Impulse Response Factor for All Sample, Small, Medium and Big Size Bank
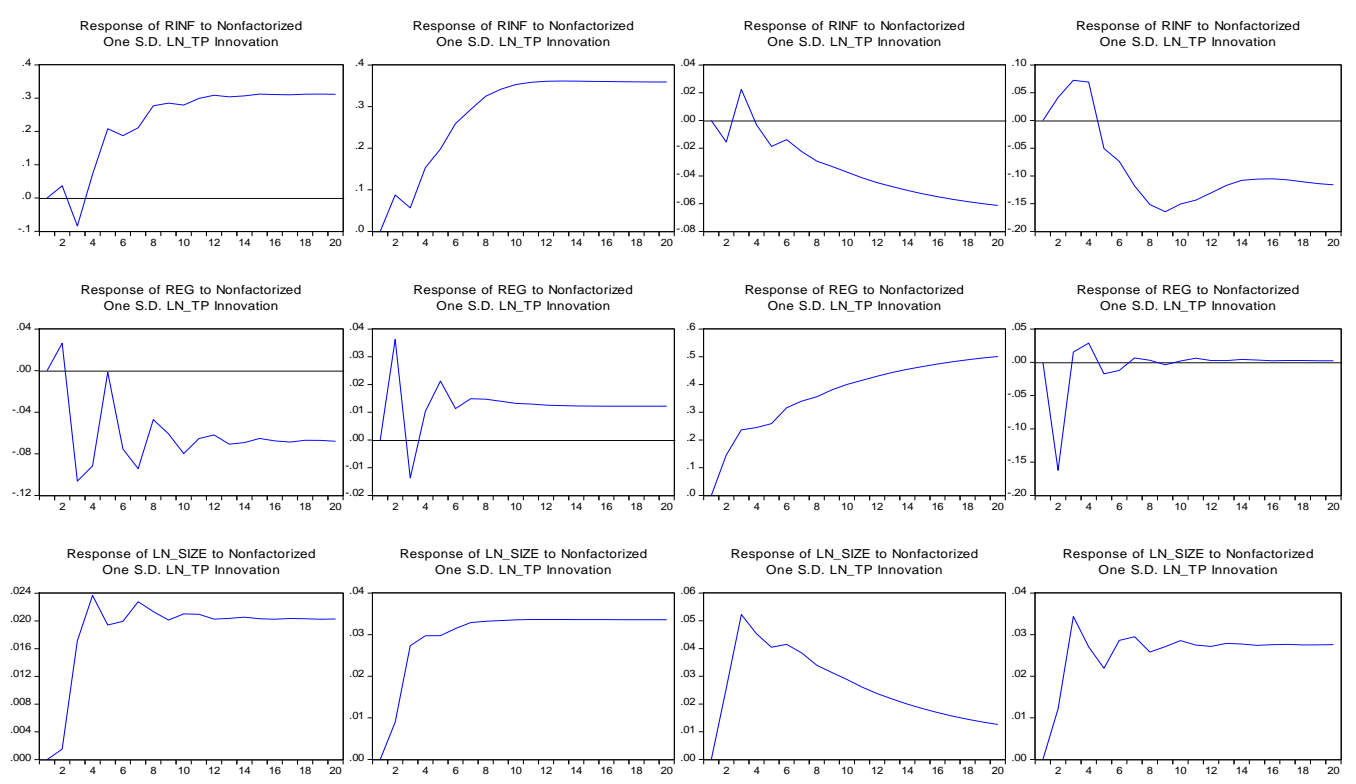

For the small size Islamic rural bank, regional inflation had a positive upward trend toward total financing. The trend consistently increased until the 1st quarter of 2015, and it moved steadily until the end of the period. That condition was different from regional economic growth, which had a dynamic movement along the observation period. Increasing sharply in the beginning, the influence of regional inflation on the total financing of Islamic rural banks dropped below the zero lines until the 3rd quarter of 2013. After that date, the influence rose under zero line and inclined stagnant since the 1st quarter of 2014 to the end of the observation period. Regarding medium size Islamic rural banks, the variable of regional inflation overall had a negative trend toward total financing of Islamic rural banks during the observation period, even though in the 2nd quarter of 2013, it had an upward trend until the 3rd quarter of 2013, then it fell in the next period. In addition, regional economic growth regularly increased until the 4th quarter of 2017. Dissimilar to regional economic growth, size had a rise in a direction until the 4th quarter of 2013 , and it plunged until the end of the period.

Lastly, big size Islamic rural banks had a different direction from other samples' groups toward total financing. Regional inflation showed an upward movement toward total financing; however, it fell from 4th quarter 2013 until the end of the observation period below the zero lines. From the perspective of regional economic growth to total financing of Islamic rural banks, downward movement occurred until the 2nd quarter 2013; after that, it increased until around the 4th quarter of 2013. Next, the direction fluctuated 
around zero horizontal lines until the end of the observation period. In terms of size effect on the total financing of Islamic rural banks, a dynamic movement also occurred in the relationship between variables. Starting to increase sharply from the beginning until around 4th quarter 2013, the movement after that decreased, and then a dynamic movement appeared after that period, which was a specific time, the influence of size on the total financing increased or decreased consecutively.

\section{Conclusion}

Total financing of Islamic rural banks, regional inflation, and regional economic growth had a long-run integration. This finding exhibits that independent variables in this research would determine the long-run effect on the total financing of Islamic rural banks in Indonesia. Specifically, the influence should be taken as a concern for big sized Islamic rural banks even though they tended to have better risk management than other sizes of Islamic rural banks. In the short-run analysis, by adopting variance decompositions, all regional macroeconomics variables influenced less than $10 \%$ on the total financing of Islamic rural banks throughout the observation period except regional economic growth for medium size Islamic rural banks, which reached $20.3 \%$ at the end of the observation period. In addition, the direction of all regional macroeconomic variables varied for each sample group in the short run. It can be interpreted that the regional macroeconomics variable effect on total financing might depend on the economic situation and Islamic rural bank's financial soundness.

According to the result, Islamic rural banks in Indonesia should be aware of the regional macroeconomic variables. It may be essential to maintain the stability of Islamic rural bank financing. Moreover, as an authority, the central bank is also recommended to maintain the inflation rate at the safety level for the financial industry by following the determined inflation target through appropriate monetary policy. This recommendation for the central bank is aimed to maintain and boost Islamic rural bank's financing that will benefit the financial industry in Indonesia. To extend the findings for future research, this paper recommends examining the cut off level of macroeconomic variables that will contribute and not contribute to the financing development in Islamic rural banks. Thus, the effect of macroeconomic variables on Islamic rural bank financing can be comprehensively informed.

\section{Acknowledgment}

I gratefully acknowledge the support from Direktorat Penelitian dan Pengabdian Masyarakat (DPPM) Universitas Islam Indonesia for providing research grant (No:

05/Dir/DPPM/70/Pen.Pemula/PII/XI/2019) to this study.

\section{References}

Abedifar, P., Molyneux, P., \& Tarazi, A. (2013). Risk in Islamic banking. Review of Finance, 
Asia Pacific Foundation of Canada. (2018). 2018 Survey of Entrepreneurs and MSMEs in Indonesia; Building The Capacity of SMEs Through Human Capital.

Benczúr, P., Karagiannis, S., \& Kvedaras, V. (2019). Finance and economic growth: financing structure and non-linear impact. Journal of Macroeconomics, 62, 1-28. https://doi.org/10.1016/i.jmacro.2018.08.001

Boyd, J. H., \& Champ, B. (2006). Inflation, Banking, and Economic Growth. Federal Reserve Bank of Cleveland, 1-4.

Carlos, M., Ferreira, H., \& Mendonça, D. (2011). Macroeconomic relevance of credit channels : Evidence from an emerging economy under inflation targeting. Economic Modelling, 28(3), 965-979. https://doi.org/10.1016/j.econmod.2010.11.012

Chiu, T.-K. (2017). Factors Influencing Microfinance Engagements by Formal Financial Institutions. Journal of Business Ethics, 143(3), 1-23. https://doi.org/10.1007/s10551015-2811-1

Chong, B. S., \& Liu, M. H. (2009). Islamic banking: Interest-free or interest-based? PacificBasin Finance Journal, 17(1), 125-144. https://doi.org/10.1016/i.pacfin.2007.12.003

Fakhrunnas, F., \& Imron, M. A. (2019). Assessing Financial Risk and Regional Macroeconomic Influence to Islamic Rural Bank Performance. Global Review of Islamic Economics and Business, 7(1), 49-55. Retrieved from https://media.neliti.com/media/publications/296478-assessing-financial-risk-andregional-ma-7edbb4fa.pdf

Fakhrunnas, F., Dari, W., \& Mifrahi, M. N. (2018). Macroeconomic effect and risk-taking behavior in a dual banking system. Economic Journal of Emerging Market, 10(2), 165-176. https://doi.org/10.20885/ejem.vol10.iss2.art5

Farhan, M., Sattar, A., Chaudhry, A. H., \& Khalil, F. (2012). Economic Determinants of Non-Performing Loans: Perception of Pakistani Bank. European Journal of Business and Management, 4(19), 87-99. Retrieved from https://www.iiste.org/Journals/index.php/EJBM/article/view/3588

Garcia-Herrero, A., Gavilá, S., \& Santabárbara, D. (2009). What Explains the Low Profitability of Chinese Banks? Journal of Banking \& Finance, 33, 2080-2092. https://doi.org/10.1016/j.jbankfin.2009.05.005

Ibrahim, M. H., \& Rizvi, S. A. R. (2017). Do we need bigger Islamic banks? An assessment of bank stability. Journal of Multinational Financial Management, 40, 77-91. https://doi.org/10.1016/i.mulfin.2017.05.002

Imam, P., \& Kpodar, K. (2016). Islamic banking: Good for growth? Economic Modelling, 59, 387-401. https://doi.org/10.1016/j.econmod.2016.08.004

Juwana, H., Berlinti, Y. S., \& Dewi, Y. K. (2014). Shariah Law As A System of Governance in Indonesia: The Development of Islamic Finance Law. Wisconsin International Law Journal, 25(4), 774-795. https://doi.org/10.1525/sp.2007.54.1.23

Levin, A., Lin, C. F., \& Chu, C. S. J. (2002). Unit root tests in panel data: Asymptotic and finite-sample properties. Journal of Econometrics, 108(1), 1-24. https://doi.org/10.1016/S0304-4076(01)00098-7

Otoritas Jasa Keuangan (2018). Statistik Perbankan Syariah. Retrieved from https://www.ojk.go.id/id/kanal/syariah/data-dan-statistik/statistik-perbankansyariah/Pages/Statistik-Perbankan-Syariah---Desember-2018.aspx

Pedroni, P. (2000). Fully Modified OLS for Heterogeneous Cointegrated Panels. Advances in Econometrics, 15, 93-130. https://doi.org/10.1016/S0731-9053(00)15004-2

Pedroni, P. (2004). Panel Cointegration: Asymptotic and Finite Sample Properties of Pooled Time Series Tests With an Application to The Econometric. Econometric Theory, 20(3), 597-625. https://doi.org/10.1017/S0266466604203073 


\section{Fakhrunnas}

Total Financing of Islamic Rural Banks and Regional Macroeconomic Factors: ...

Perron, P. (1991). Test Consistency with Varying Sampling Frequency. Econometric Theory, 7(3), 341-368. https://doi.org/10.1017/S0266466600004503

Pesaran, M. H., \& Shin, Y. (1999). An autoregressive distributed lag modeling approach to cointegration analysis, in Strom, S. (Ed.). Paper presented at Econometrics and Economics Theory in the 20th Century: The Ragnar Frisch Centennial Symposium, Cambridge University Press, Cambridge.

Rosylin, M. Y., \& Bahlous, M. (2013). Islamic banking and economic growth in GCC \& East Asia countries. Journal of Islamic Accounting and Business Research, 4(2), 151-172. https://doi.org/10.1108/JIABR-07-2012-0044

Sari, M. D., Bahari, Z., \& Hamat, Z. (2016). History of Islamic Bank in Indonesia : Issues Behind Its Establishment. International Journal of Finance and Banking Research, 2(5), 178 184. https://doi.org/10.11648/i.ijfbr.20160205.13

Sufian, F. (2009). Determinants of Bank Profitability in a Developing Economy : Empirical Evidence from the China Banking Sector Determinants of Bank Profitability in a Developing Economy : Empirical Evidence from the China Banking Sector. Journal of Asia-Pacific Business, 10(2009), 37-41. https://doi.org/10.1080/10599230903340205

Tan, Y., \& Floros, C. (2012). Bank profitability and inflation : the case of China. Journal of Economic Studies, 39(6), 675-696. https://doi.org/10.1108/01443581211274610

Undang-Undang Nomor 21 Tahun 2008 Tentang Perbankan Syariah.

Zarrouk, H., Ben Jedidia, K., \& Moualhi, M. (2016). Is Islamic bank profitability driven by same forces as conventional banks? International Journal of Islamic and Middle Eastern Finance and Management, 9(1), 46-66. https://doi.org/10.1108/IMEFM-12-2014-0120

Zulkhibri, M., Naiya, I., \& Ghazal, R. (2015). Structural Change and Economic Growth in Selected Emerging Economics. International Journal of Development Issues, 14(2), 98-116. https://doi.org/10.1108/MBE-09-2016-0047 